\title{
Teologi Bencana dan Rekonstruksi Etika Pembangunan (Perspektif Islam)
}

\author{
Agus Triyanta
}

The following article investigates disaster of earthquake from Islamic ethics point of view. Disaster or earthquake constitute an active learning that given by God by natural phenomenon in order to human introspect, human life in accordant with the urgent need of keeping universe. Islam as a religion to give high motivation in order to answer the ultimate question and optimistic of life. Last but not least, it should be reconstruct religious ethical norms in term of human invironmental development. Happening disaster either as the God's involvment or the rasionality of natural phenomenon.

Kata kunci: teologi bencana, etika dan Islam

5 encana, sepanjang sejarah kehidupan, telah menghasilkan dua hal, pesimisme dan optimisme sekaligus. Bagi sementara orang, pessimisme akan muncul bila ternyata keberagamaan yang telah dibangun, kepercayaan pada Tuhan, ibadah yang dilakukan, tidak menjadikan mereka terhindar dari bencana. Bagi mereka, seakan, Tuhan tetap saja 'membenci' mereka, menjadikan hidup mereka berkesusahan. Karenanya, sebagaimana yang terjadi di Spanyol, bencana justeru mendorong sekularisasi. Untuk apa percaya Tuhan dan agama bila ternyata agama telah gagal menyelamatkan mereka. Mengapa Tuhan tetap menghancurkan orang-orang yang mengabdi kepadaNya.'Inilah pandangan yang sangat skeptis terhadap perlunya agama. Maksudnya, pandangan yang menganggap bahwa agama adalah tempat pelarian ketika berbagai masalah menghadang, dan ketika ternyata dengan menganut agama berbagai problema dan kesulitan tetap dihadapi, maka kemudian mereka kecewa terhadap keberagamaan mereka.

Sebaliknya, bagi sementara orang yang lain, fenomena bencana akan disikapi secara optimis dan diterima sebagai 'peringatan' dan 'sapaan' Tuhan karena rendahnya kualitas beragama, atau karena terjadinya penyimpangan dalam beragama, ataupun juga karena tidak adanya upaya lahiriah bagi pewujudan kehidupan yang lebih baik.Meski demikian, masih dalam pandangan ini,lahirlah konsep yang dalam teologi Islam disebut istidraj, ${ }^{2}$ ialah bahwa

1 Mohamad, Goenawan, 'Tsunami', dalam, Tempo, Edisi 10-16 Januari 2005

2 Secara litterliijk, istidraj berarti mendekatkan atau meningkatkan, namun 
tidak selamanya orang yang ingkar itu lantas diberikan siksa dunia yang bisa terjadi antara lain berupa bencana, karena Allah sengaja 'membiarkan' mereka, 'tidak mau tahu' dengan mereka sebagaimana mereka pun tidak pernah punya komitmen kesetiaan kepada Allah (Tuhan), mereka tidak pernah mengikrarkan sesuatu sebagai lambang penghambaan pada Tuhan. Karenanya, justeru dalam perspektif yang kedua ini, bencana akan dimaknai sebagai lambang kasih sayang Tuhan sehingga Tuhan masih mengingatkan dan tidak membiarkan hambanya dalam kesesatan yang nyata (dhalal al-mubin), atau jika bukan peringatan, akan diposisikan bencana itu sebagai ujian, di mana, berlakulah logika ujian, bahwa seseorang hanya akan bisa 'naik kelas' apabila melalui ujian, dan apabila ada orang yang bisa 'naik kelas' tanpa ujian, pastilah itu bukan cara yang benar dan alami yang benar. Akhirnya diyakjinilah bahwa ujian adalah momentum peningkatan kualitas.

Bahkan, kembali kepada kelompok yang merespon bencana secara negatif $d i$ atas, akibat dari bencana bisa lebih fatal lagi. Bagi kelompok yang pesimistis ini, pelampiasan selanjutnya bisa terjadi lebih buruk, ialah dengan mengabaikan pembangunan lingkungan dan berbagai upaya perbaikan prasara kehidupan dengan asumsi bahwa ternyata meskipun pernbangunan lingkungan telah dilakukan, tetap juga bencana datang. Berarti, dalam pandangan mereka, bencana adalah sebuah takdir Tuhan yang sama sekali manusia tidak memiliki peran dalam kejadiannya, sesuatu yang sudah given dan tidak perlu dicari makna positifnya.

Tulisan ini bermaksud menganalisa fenomena bencana dari sudut pandang teologis-etis, yakni dari aspek konsep keimanan dan etika dalam Islam. Bagaimana fenomena bencana harus dipahami, mengapa peristiwa itu terjadi, apa nilai yang tersembunyi dari adanya bencana, apakah rahasia teologis yang bisa diungkap mengapa Tuhan -sebagai dzat yang Maha Kuasa- menjadikan bencana, hal yang dipandang sebagai kekejaman oleh sebagian besar manusia, dan terakhir, bagaimana agama mengajarkan optimisme dalam merespon bencana dengan reorientasi etika pembangunan yang religius.

\section{Bencana: Rekayasa Tuhan versus Fenomena Alam}

Meski dalam kondisi awalnya sulit dipahami, namun berbagai peristiwa bencana besaryang direkam oleh al-Qur'an biasanya akan mendapatkan eksplanasi ilmiahnya di masa-masa berikutnya, utamanya adalah masa-masa modem yang melahirkan banyak penemuan dan inovasi ilmiah. Sehingga pertanyaan dialektis yang muncul kemudian adalah apakah bencana yang terjadi itu merupakan musibah, peringatan atau ujian dari Tuhan, yang harus dipikirkan déngan 'logika prophetik' terlepas dan rasionalisme ilmiah, ataukah sebaliknya, bahwa itu semua semata-mata fenomena alam yang dengan segala naturalitasnya akan memiliki siklus-siklus disasteryang suatu saat muncul dengan berbagai sebab yang rasional juga, yang tidak ada kaitannya sama sekali dengan keberagamaan manusia?.

Pertanyaan inj tidak bisa dijawab dengan mudah, karena kehendak Tuhan

secara istilah biasa dimaknai dengan tindakan Allah membiarkan perilaku maksiat orang-orang kafir. Munawir, Ahmad Warson, Kamus Al-Munawir. 1997. (Surabaya: Pustaka Progressif) hlm.395. Juga, Uman, Cholil, et:al. 1995. Kamus Pintar Agama Islam (Bandung: Citra umbara) hlm 105. 
adalah suatu hal yang gaib (beyord imagination) yang sulit ditentukan maksud yang terkandung dalam suatu peristiwa, namun paling tidak etika teologis mengajarkan pada manusia untuk senantiasa belajar dari fenomena alam. Dengan dasar jtulah kemudian menjadi penting bagaimana pertanyaan tersebut bisa disikapi secara lebih fair.

Berbagai bencana besar dalam alQur'an yang seakan-akan merupakan sesuatu yang serba dahsyat dan tidak bisa dilogika baik pada setting masyarakat yang ada di masa terjadinya peristiwa tersebut ataupun juga pada masyarakat di mana dan ketika al-Qur'an tersebut diwahyukan, hari ini, setelah puluhan abad berikutnya, berbagai peristiwa yang diberitakan kitab suci tersebut telah menjadi obyek studi yang menghasilkan pemahaman yang sangat rasional terhadap berbagai peristiwa masa lalu tersebut. Misalnya saja, dalam peristiwa bencana hancurnya kaum Gomorah dan Soddom, yakni umat dari Nabi Nuh AS, yang mereka itu telah bergelimang dalam dosa dengan menjadikan suatu hal yang keji sebagai perilaku yang biasa, ialah lesbian dan homoseks (liwath). ${ }^{3}$ Peristiwa yang dalam Al-Qur'an disebut sebagai hujan batu dari langit (hijarah min al-sama) itu ternyata berdasarkan riset yang telah dilakukan para ahli (ilmuwan), telah diungkap sebagai sebuah peristiwa ledakan vulkanis yang sangat besar. Ledakan tersebut menye= babkan semacam 'hujan batu' dikarenakan bebatuan yang disemburkan oleh magma yang mengalami erupsi. ${ }^{4}$ Kemudian, ledakan tersebut telah mengakibatkan juga semacam patahan yang mengakibatkan bumi /lapisan tanah terbalik, yang dalam al-Qur'an diindikasikan dengan kata-kata waja'alna adnaha safilaha (bagian bawah menjadi atas dan bagian atas menjadi berada di bawah). Penemuan ilmiah ini dikuatkan dengan bukti- bukti tekstur dan kontur tanah di seputar laut mati, di mana lokasi laut mati tersebut . ternyata adalah bekas pemukiman mereka yang turun karena patahan bumi.

Demikian juga, suatu wabah yang sangat sulit dipahami yang berupa musibah yang menimpa penduduk Mesir pada masa pemerintahan Fir'aun (Pharaoh/Ramses), yakni bahwa Sungai Nil telah mengalir darah, yang karenanya airnya tidak bisa lagi diminum oleh penduduk Mesir Kuno, padahal mereka menggantungkan kehidupannya, baik untuk kepentingan konsumsi maupun transportasi pada Sungai Nil, dan menjadilah hal itu sebagai bencana besar di era Fir'aun. Ungkapan al-Qur'an yang semacam ini, ternyata setelah dilakukannya berbagai riset, terungkaplah bahwa yang menyebabkan air sungai Nil berwarna merah bukanlah darah, namun ternyata adalah munculnya tumbuhan semacam protozoa dan zooplankton yang sangat beracun, yang akhirnya makhluk tersebut telah menjadikan warna sungai Nil seakan-akan berwarna darah. Berbagai bukti tidak normalnya siklus (mata rantai) kehidupan di masa Firaun ternyata telah mendorong terjadinya berbagai musibah yang susul-menyusul, bukan hanya 'banjir darah', namun juga overpopulasi belalang dan katak. Sebagaimana diurai secara singkat oleh hasil penelitian modem sebagai berikut: - -

"Recent explanations of the cause for the red colouring of water has favoured protozoan, zooplankton, both salt-and

${ }^{3}$ QS. Al-A'raf (7) : 133.

${ }^{4}$ Harun Yahya. 1999. Persihed Nations, translasi ke Inggris, Ahmad, Mustapha (London: Ta-Ha Publisher Lid) hlm. 42-63. Sebagian besar dari buku ini juga menceritakan berbagai bentuk proses pengancuran berbagai bangsa sebelum Islam. 
fresh- water algal (phytoplankton) blooms, and dinoflagellates. All of these various blooms - plang, fungal or protozoan-deoxygenate water and produce noxious toxins for both fish and frogs."

Di sini ada pertanyaan berkaitan dengan letak human error (kesalahan manusia) dalam sebuah bencana. Jika dilihat dari berbagai eksplanasi ilmiah terhadap terjadinya bencana sebagaimana beberapa contoh di atas, maka kemudian muncul pertanyaan, dimanakah letak kesalahan manusia dalam kasus-kasus tersebut, yang karenanya sekelompok manusia harus menerima bencana?. Atau sebaliknya, bukankah dengan adanya éksplanasi yang menunjukkan betapa alamiahnya bencana tersebut, akan muncul kesan bahwa bencana tersebut terjadi secara alamiah dan tidak ada kaitannya sama-sekali dengan (kesalahan) perbuatan manusia dilihat dari sudut pandang ajaran agama?.

Dalam tingkat tertentu, memang kesalahan manusia tidak selalu nampak dalam kasus-kasus bencana yang terjadi. Karena ternyata, adanya berbagai eksplanasi ilmiah yang tidak menunjukkan kausalitas ilmiah antara perilaku manusia terhadap bencana alam tersebut. Misalnya datangnya gempa bumi. Sulit dikatakan bahwa gempa bumi terjadi karena hubungan kausalitas antara alam dan ulah manusia. Meski demikian, ketentuan yang tidak bisa dijelaskan secara ilmiah juga akan senantiasa muncul dalam terjadinya sebuah bencana. Ketika bencana menimpa sekelompok orang tertentu misalnya, meskipun peristiwanya sendiri bisa dijelaskan secara ilmiah, namun tentang mengapa orang-orang tersebut yang menjadi korban, dan mengapa 'kebetulan' bukan orang lain yang terkena, adalah sesuatu yang tidak bisa dijelaskan secara empiris-ilmiah, namun hanya bisa dijelaskan dengan aspek teologis. Jadi, pertanyaan tentang fenomena apakah yang dinamakan 'hujan batu' masa Nabi Luth, bisa dijelaskan dengan ilimiah, namun, pertanyaan tentang 'mengapa yang tinggal di situ adalah orang-orang masa nabi Luth yang memiliki kelakuan menyimpang, dan bukannya komunitas lain, adalah suatu hal yang sulit dijawab, dan jawabannya dimungkinkan akan berhenti pada bahwa semua kejadian itu adalah sebuah destiny. Sehingga, bagaimanapun juga logis dan rasionalnya sebuah bencana alam ditinjau dari ilmu pengetahuan, namun tetap juga terkandung rahasia, minimal pada 'nasib' orang-orang tertentu yang terkena bencana, mengapakah mereka yang terkena bencana, dan bukannya orang lain.

Pada titik ini, sebenarnya, hampir pada setiap bencana yang terjadi dalam sebuah masyarakat, akan menyisakan suatu bagian yang tidak bisa dijelaskan secara ilmiah, melainkan tetap memerlukan kerja kontemplasi emosional yang akan lebih dapat menjelaskan aspek-aspeknon-ilmiah empiris.

\section{Pandangan Ulama Terhadap Bencana}

Islam sebagaj sebuah agama yang mendeklarasikan diri sebagai agama yang lengkap dan universai ${ }^{6}$, sudah barang tentu memiljki weistanchaung tersendiri terhap berbagai fenomena yang ada dalam kehidupan ini, tak terlepas darinya adalah fenomena bencana yang menimpa sebuah komunitas. Pandangan dunia yang spesifik itulah justeru, yang banyak dikritik oleh banyak pihak sebagai pemahaman yang
5 lbid. hlm 105.
${ }^{6}$ QS. Al-Maidah (5) : (5). 
tidak memberikan optimisme bagi orangorang yang baik secara langsung maupun tidak langsung terkena bencana, ialah karena orang yang menderita akibat bencana akan didudukkan sebagai komunitas yang layak disiksa oleh Tuhan, atau bahkan layak dimusnahkan. Meski sebaliknya, pandangan yang spesifik tersebut juga bisa dipahami oleh pihak lain, utamanya yang sepakat dengan pandangan tersebut, sebagai sarana untuk memotivasi agar manusia selalu membangun komitmen etika religius dalam melakukan pemberdayaan sumber daya alam selama hidup di dunia ini.

Untuk lebih memperjelas pemahaman terhadap cara pandang yang dimaksud $\mathrm{di}$ atas, perlu disampaikan di sini bahwa agama Islam memiliki cara pandang tersendiri dalam kaitannya dengan terjadinya sebuah bencana yang menimpa sebuah masyarakat (kaum). Secara general, para ulama mempersepsikan bencana dengan versi sebagai berikut: ${ }^{7}$

Pertama, bencana sebagai ujian. Suatu musibah akan dipandang sebagai ujian apabila bencana tersebut pada kenyataannya menimpa (dikenakan oleh Allah) pada orang-orang yang memang perbuatannya baik, tidak bertentangan dengan prinsip-prinsip Islam. Artinya orang atau sekelompok orang yang dimaksud sudah berbuat sesuai dengan aturan-aturan yang diperintahkan oleh agama, atau sebaliknya menjauhi hal-hal yang dilarang di dalamnya. Di sini, sekelompok manusia dikenai bencana bukan karena penyelewengan, tetapi karena memang semata-mata Allah berkeinginan untuk menguji mereka. Ujian, tentu saja berkaitan dengan upaya untuk mengetahui tingkat komitmen dan konsistensi orang-orang yang beriman dalam memegang prinsip-prinsip Islam. Pemahaman terhadap bencana yang semacam ini mendasarkan pada ayat alQur'an yang menyatakan bahwa setiap pernyataan keimanan mesti akan diuji oleh Allah ${ }^{\natural}$, juga ayat yang berisi tentang pertanyaan retoris apakah orang-orang yang beriman akan dibiarkan tanpa diuji oleh Allah. ${ }^{\circ} \mathrm{Di}$ sini, sebuah bencana itu akan dinilai sebagai bentuk kasih sayang Tuhan pada hambanya, sebagaimana tersirat dari sebuah pernyataan teologis :"Idza ahabballahu 'abdan ibtalah", artinya, "Jika Allah mencintai seorang hamba, tentu akan mengujinya". Sehingga bisa dikatakan bahwa tipe bencana yang semacam ini merupakan suatu bencana yang paling tinggi maknanya bagi orang beriman.

Kedua, bencana sebagai peringatan. Interpretasi ini memiliki maksud bahwa orang beriman adalah orang yang telah ber'transaksi' dengan Allah swt, bahwa orang tersebut akan setia menjalankan perintah dan menjauhi larangan. Dengan kata lain, itulah yang namanya orang ber-Islam, ialah "berserah diri pada semua aturan Allah" (istislam). Maka, atas dasar logika seperti ini, seseorang yang menyalahi perintah Allah, dia akan dikontrol oleh Allah karena Allah telah 'memandang' orang tersebut sebagai hamba yang harus dikasihi, dijaga agar terhindar dari keterperosokan dalam agama. Oleh karena itu, dalam logika ini, peringatan akan bersifat gradual, dari peringatan yang hanya berupa untaian katakata dalam ayat-ayat al-Qur'an maupun teks sunnah Nabi, sampai dengan 'teguran' yang keras, yang hal itu bisa berupa, antara lain, bencana alam. Referensi teologis dari interpretasi semacam ini bisa didapati dalam al-Qur'an, yang menyatakan "..dan apapun

${ }^{7}$ Sebagian penjelasan bisa dilihat pada, Uman, ibid.

${ }^{8}$ QS.Al-Baqarah (2): 214

${ }^{\circ}$ QS. Al-Ankabut (29) : (2-3). 
yang menimpamu, pada hakekatnya disebabkan karena faktor dari dirimu". ${ }^{10}$

Ketiga, bencana sebagai siksaan/ kutukan. Siksaan atau kutukan, atau yang lebih vulgar adalah 'pembinásaan', memang bukan wacana yang asing dalam al-Qur'an. Banyak bangsa (kaum) sebelum datangnya Islam yang dibawa oleh Nabi Muhammad S.A.W, yang telah dibinasakan. $\mathrm{Hal}$ itu, masih menurut al-Qur'an dan welstanchaung Islam versi ini, dikarenakan penentangan mereka terhadap para Nabi. Di mana mereka senantiasa berupaya untuk menangkap dan mengintimidasi para Nabi dan orang-orang beriman. Karena buruknya perilaku mereka, hingga ada doa-doa yang terlontar yang berisi permohonan kepada Allah untuk membinasakan saja mereka tersebut. Misalnya adalah doa Nabi Nuh yang menginginkan agar orang kafir dibinasakan karena 'mereka adalah orang sesat, yang jika dibiarkan tidak akan menurunkan generasi kecuali generasi yang fajir dan kafir." Dan kemudian, memang, sebagaimana fakta yang terjadi, kaum Nabi Nuh terbinasakan dengan air bah. Dalam kesempatan lain, al-Qur'an juga menyebut kata-kata di seputar dimungkinkannya penggantian sebuah generasi dengan generasi lain, hal itu disebabkan generasi pertama dinilai melakukan pembangkangan, maka akan didatangkanlah kemudian generasi pengganti yang lebih baik. ${ }^{12}$

Demikian interpretasi teologi klasik yang banyak diyakini dalam kaitannya dengan terjadinya sebuah bencana. Meski interpretasi semacam tidak bisa ditolak, namun, pendekatan yang optimis harus dibangun dalam upaya menyikapi terjadinya sebuah bencana, dan bukannya pendekatan klasik yang sangat jabariy (predestinatif) ${ }^{\prime 3}$. Yang dimaksudkan dengan pendekatan yang jabariy adalah suatu sudut pandang yang meletakkan manusia sebagai makhluk yang pasif, yang tidak memiliki sedikitpun andil dalam terjadinya suatu peristiwa. Sehingga, sudut pandang ini akan menawarkan pesimisme dan frustasi, di mana, manusia tidak perlu banyak berupaya dengan melakukan inovasi dan perbaikan manajemen sumber daya alam agar bisa terhindar dari berbagai bencana yang mungkin terjadi di masa mendatang. Artinya, bahwa semua yang tejadi terhadap manusia haruslah ditangkap sebagai sebuah pembelajaran yang daripadanya bisa dianalisis dan dicari, apa kelemahan manusia dan aspek-aspek terkait apa saja yang masih bisa diperbaiki. Sehingga, bencana justeru merupakan momentum kebangkitan dan rekonstruksi nilai-nilai etika yang lebih baik, utamanya adalah dalam etika pembangunan yang lebih memperhatikan keramahan terhadap lingkungan.

Dalam kaitannya dengan fungsi bencana sebagai ujian, harus dipahami juga bahwa di lingkungan orang yang beragama (Islam), ada persepsi bencana yang berbeda dengan pandangan umum (eksklusif). Jadi, keberagamaan, dalam hal lain, juga menawarkan analisis yang lain terhadap bencana. lalah berkait dengan konsep
${ }^{10}$ QS.42: 30
"QS. Nuh (71) : (21)
${ }^{12}$ QS. Al-Maidah (5) : (54).

${ }^{13}$ Jabariyyah adalah sebuah aliran teologi dalam Islam yang berpendapat bahwa manusia tidak memiliki peran sama sekali terhadap peristiwa, termasuk yang terjadi dengan dirinya. Aliran ini dipopulerkan oleh Ja'ad bin Dirham dan disusun teori dan tetorikanya oleh Jaham bin Sofyan, dalam, Efendy, Mochtar. 2001. Ensiklopedi Agama dan Filsafat, Buku 3. (Palembang: Penerbit Universitas Sriwijaya).hlm.3. Lihat juga, Al-Faruqi, Ismail R, dan Al-Faruqui, Louis Lamya. 1998. Atlas Budaya, terjemah Hasan, llyas. (Bandung: Mizan) hlm. 316. 
kesedihan. Agama, memberikan kepada pemeluknya konsep yang spesifik tentang pleasure and pain (kosep kenikmatan dan kesakitan. ${ }^{14}$ Dalam pendekatan ini, kebahagiaan dan kesedihan tidak bisa disamakan dengan pandangan materialisempiris. Agama semakin memberikan ketegasan bahwa aspek relativismesubyektif dalam merespon sesuatu merupakan instrumen yang sangat niscaya. Bagi outsider, apa yang diderita seseorang barangkali akan dianggap sebagai kesengsaraan, namun bagi yang mengalami (insider) hal itu adalah suatu kebahagiaan.

Dalam konsep sufisme Islam, dikenallah apa yang disebut dengan extacy, ialah suatu kondisi di mana seorang hamba mencapai kebahagiaan hidup dalam pengabdian kepada Tuhan. ${ }^{15}$ Konsep ini sebenarnya tidak akan jauh dari konsep mencinta, di mana bagi orangyang memiliki cinta dalam tingkatan yang relatif tinggi, dia akan dibawa oleh kondisi psikologis untuk merasakan sebuah penderitaan menjadi kebahagiaan.

Sehingga, orang yang terkena musibah, dalam pandangan Islam, bisa saja menyikapi tidak dengan perasaan yang menderita, namun dengan keikhlasan yang penuh dengan motivasi untuk maju dan berkembang, menghindari berbagai tindakan destruktif yang sebelumnya banyak dilakukan. Sehingga, bagi orang yang beragama (Islam), adanya bencana tidak akan mendorong pada fatalisme dan keterjebakan dalam pesimisme dan keputusasaan, namun sebaliknya, akan disikapi secara positif dan konstruktif, bahwa tidak ada kesadaran yang tidak didahului dengan kesulitan. Berarti, hal ini merupakan aspek lain dari agama yang bisa membangkitkan optimisme dalam merespon sebuah bencana.
Setelah membahas tentang pandangan agama terhadap bencana, di sini perlu juga dianalisis tentang fungsi agama sebagai tempat untuk mendapatkan jawaban dari berbagai pertanyaan kehidupan yang fundamental. Hal ini karena dengan membahas aspek ini, akan lebih jelas bagaimana optimisme pasca bencana akan bukan hanya mudah, namun juga sangat relevan untuk dibangun.

\section{Agama dan Jawaban Terhadap 'The Ultimate Question'}

Di antara faktor yang mendorong mengapa manusia membutuhkan agama adalah bahwa manusia tersebut membutuhkan jawaban atas berbagai permasalahan puncak, (the ultimate question) dalam kehidupan yang tidak bisa dijawab dengan eksplorasi akal yang dimilikinya. ${ }^{16}$ Bagaimanapun sempurnanya akal sebagai instrumen inovasi manusia, ternyata akal tetap saja mengandung banyak kelemahan, sebagaimana diakui juga hal ini oleh para filsuf barat modem. ${ }^{17}$ Jawaban dari

\footnotetext{
${ }^{14}$ Paden, William A. 1994. Religious Word (Massachussets: Beacon Press) hlm.ix-x.

15 Triyanta, Agus.2002. Pandangan Tarekat Naqsabandiyah terhadap Konservasi Alam, penelitian individual Lembaga Penelitian Universitas Islam Indonesia.

${ }^{16}$ Dister, Niko Syukur.1988. Pengalaman dan Motivasi Beragama. (Yogyakarta: Kanisius) hlm. 78 dan 104. Juga, Bagir, Haedar, dalam pengantar karya Schimmel, Annemarie.1996. Rahasia Wajah Suci Ilahi, terjemah Astuti, Rahmani. (Bandung: Mizan) hIm.12

17 Immanuel Kant dan David Hume adalah di antara pemikir (filsuf) barat yang berpendirian bahwa akal manusia memiliki banyak kelemahan. Karenanya, hanya dengan mengandalkan akal saja, tidak semua permasalahan yang dihadapi manusia
} 
permasalahan puncak tersebut, hanyalah bisa didapat lewat agama. Karena itulah, manusia tetap memerlukan agama sebagai 'tempat suaka' terakhir.

Dalam kaitannya dengan bencana, jelas, terdapat banyak hal yang beyond imagination'atau tidak pemah dibayangkan dengan nalar sehat. Sebagaimana diungkap dalam pembahasan di depan, meskipun fenomena bencana bisa dipahami latar belakang dan proses kejadiannya secara ilmiah modern, namun pertanyaan tentang, mengapakah orang-orang tersebut yang harus mati di 'tangan' bencana, dan bukannya orang lain, adalah sebuah pertanyaaan yang tidak bisa dijawab dengan akal manusia. Nasib apa yang telah membawa mereka untuk berada di tempat tersebut ketika bencana terjadi, dan mengapa ada sebagian penduduk lokasi bencana yang seakan 'diselamatkan' karena sedang tidak ada di lokasi bencana. Di sini tetap saja menyiratkan adanya suatu pertanyaan yang tidak bisa terjawab, karenanya, tidak ada cara dan pendekatan lain yang bisa digunakan untuk memahami kecuali agama. Dan sebenarnya, begitulah bahwa bukan hanya dibalik sebuah bencana, di balik sebuah peristiwa besar, pasti akan tersisa sebuah pertanyaan yang sulit dicari jawabnya. Itulah mengapa, Tuhan, merupakan kausa prima, ialah sumber dan musabab yang paling tinggi (klimaks) atas setiap peristiwa.

Atas dasar itulah, sebuah bencana, seharusnya akan dimaknai lebih dalam dan lebih baik lewat sudut pandang agama. Karena bencana dalam pandangan yang semacam ini akan mampu 'berbicara' lebih dalam daripada sekedar dipahami secara terlepas dari agama, dengan catatan bahwa bukan sudut pandangan yang jabariy sebagaimana yang telah diurai di depan. Sehingga, agama, dalam konteks ini akan mampu lebih jauh mengantarkan kesadaran tentang perlunya upaya-upaya perbaikan perilaku manusia pada baik terhadap sesama maupun terhadap alam. Agama, dalam hal ini lebih memiliki potensi untuk memandang bencana sebagai momentum bagi dinamisitas kehidupan dan rekonstruksi nilai etika.

\section{Bencana: Membangun optimisme bagi rekonstruksi etika religius.}

Dengan pembahasan tersebut di atas, bisa dilihat bahwa bencana, bagaimanapun juga naturalnya, namun dalam beberapa hal bisa dicermati bahwa kesalahan manusia ikut berpengaruh di dalamnya. Baik aspek human error itu bersifat 'abstract-spiritual' maupun 'empiris-fisis'. Untukmenunjukkan betapa human errortelah terjadi sebenamya bisa dibuat analogi yang sederhana. Meski dengan jenis bencana yang sama, tetapi dalam berbagai kasus yang terjadi, 'daya bunuh' (killing power) sebuah bencana itu meskipun sama, tetapi akan mengakibatkan jatuhnya jumlah korban dan kerusakan prasarana yang berbeda antara di negara maju dan negara berkembang. Sebuah gempa di Indonesia, akan mengakibatkan jumlah korban yang jauh lebih besar dengan gemba yang berkekuatan sama yang terjadi di Jepang, misalnya. Demikian juga, badai laut yang sama kuatnya akan menimbulkan korban jauh lebih besar di Bangladesh meski di California kematian dan kerusakannya jauh lebih kecil. Hal itu jelas telah menunjukkan suatu kesimpulan bahwa di sini ada perbedaan perilaku manusia yang berbeda

tidaklah akan bisa diselesaikan. Di sinilah argumen yang 'memaksa' orang untuk tetap meyakini agama. (Moslehuddin, Muhamad, Philosophy of Islamic Law and the Orientalists (Comparative Study of Islamic Legal System) (Delhi: Markazi Maktaba Islami) . 
antara kedua tempat yang berbeda tersebut. Perilaku yang dimaksud adalah, sikap dan mental dalam merespon gejala bencana, upaya pembangunan teknologi yang berbeda, atau pendeknya, bagaimana upaya yang dilakukan manusia untuk meminimalisir efek tersebut. Perbedaan di sini, tentu saja akan memberikan kesim-pulan berikutnya bahwa telah terjadi keterlambatan (baca: ketidakmampuan) pengembangan teknologi penangkal di satu masyarakat dan di sisi lain, adanya responsifitas sekelompok manusia dalam mengangkat berbagai potènsi bencana.

Atas dasar analisa tersebut, maka sebenarnya tidak ada perbedaan dalam hal memahami bahwa sebuah bencana terjadi sangat mungkin akan menyisakan catatan tentang 'human error'. Sehingga, sebenarnya, sangat terbuka sebuah upaya membangun mentalitas yang menyikapi bencana sebagai sebuah 'cambuk' dan momentum untuk kehidupan yang lebih baik.

Dari sudut pandang religi, upaya menerima 'uduhan' bahwa sebuah bencana diakibatkan human emorbisa lebih mudah dipahami. Hal itu dikarenakan agama selalu memberikan peluang yang double atas setiap masalah, ialah aspek isoteris (bathiniy) maupun eksoteris (lahiriy), karenanya, kedua pendekatan ini akan bisa lebih mendudukkan permasalahan human error tersebut dengan mudah serta kemudian mencari upaya tindak lanjutnya. Meski, bisa juga yang terjadi adalah sebaliknya, ialah bahwa teologi jabariy seperti yang telah disinggung dalam bahasan di depan, bisa melahirkan sikap fatalistik, yakni terima apa adanya, dan karenanya, ini justeru akan menghambat upaya pembangunan dan inovasi teknologi. Mengapa?. Tidak lain hal itu karena pemahaman bahwa mati adalah takdiryang karenanya berbagai upaya tidak perlu ditempuh. Penghancuran sebuah komunitas lewat bencana adalah 'otoritas' Tuhan yang manusia tidak bisa sedikitpun melakukan intervensi terhadapNya, termasuk upaya penanggulangan adalah sesuatu yang akan sia-sia.

Karena itulah, yang diperlukan bagi upaya rekonstruksi inj adalah upaya rekonstruksi teologis serta rekonstruksi nilai etika pembangunan yang 'prophetik', ialah persepsi tentang takdir yang melibatkan intervensi manusia pada keterwujudannya. Paling tidak adalah pemahaman yang moderat, di mana bahwa takdir adalah sebuah resultan antara upaya maksimal manusia dengan ketentuan Allah. Di sinilah relevansinya salah satu perkataan Allah dalam al-Qur'an, bahwa, "Sesungguhnya Allah tidak merubah kondisi suatu kaum sehingga mereka sendirilah yang merubahnya". ${ }^{18}$

\section{Penutup}

Berdasarkan pembahasan di atas, bisa ditarik beberapa kesimpulan sebagai berikut:

Pertama, terjadinya bencana adalah, menurut perspektif etika Islam, adalah sebuah pembelajaran aktif yang diberikan Tuhan (Allah) lewat fenomena alam agar manusia bisa berintrospeksi, agar manusia senantiasa hidup dengan metode yang sejalan dengan kepentingan pemeliharaan alam.

Kedua, agama (Islam), sebagai tempat untukmemberikan jawaban dari the ulfimate question' akan memberikan motivasi yang tinggi agar manusia tetap optimis. Dengan tanpa adanya jawaban atas pertanyaan puncak ini, pengingkaran terhadap agama bukannya akan mampu menjadi penghibur,

${ }^{18}$ QS. 13:11 
Teologi Bencana dan Rekonstruksi Etika Pembangunan; Agus Triyanta

tetapi justeru menjadikan mereka terjebak pada hilangnya optimisme dan munculnya penyelasan diri yang berkepanjangan.

Ketiga, keharusan untuk dilakukan rekonstruksi etika religiusitas (akhlak alislamiy) dalam etika pembangunan lingkungan hidup manusia. Terjadinya bencana, baik jika dipahami dari perspekif intervensi Tuhan maupun dari rasionalitas fenomena alam, tetap saja menyisakan suatu pelajaran penting, ialah keharusan untuk dilakukan rekonstruksi nilai moralreligius bagi pembangunan dan pendayagunaan sumber daya alam.

\section{Daftar Pustaka:}

Al-Faruqi, Ismail $\mathrm{R}$, dan Al-Faruqi, Louis Lamya. 1998. Atlas Budaya, terjemah Hasan, llyas.Bandung: Mizan

Bagir, Haedar, dalam pengantar karya Schimmel, Annemarie. 1996. Rahasia Wajah Suci Ilahi, terjemah Astuti, Rahmani. Bandung: Mizan

Dister, Niko Syukur. 1988. Pengalaman dan Motivasi Beragama.Yogyakarta: Kanisius.

Efendy, Mochtar. 2001. Ensiklopedi Agama dan Filsafat, Buku 3. Palembang: Penerbit Universitas Sriwijaya.
Mohamad, Goenawan, 'Tsunami', dalam, Tempo, Edisi 10-16 Januari 2005

Moslehuddin, Muhamad, Philosophy of Islamic Law and the Orientalists Comparative Study of Islamic Legal System, Delhi: Markazi Maktaba Islami.

Munawir, Ahmad Warson,1997, Kamus AlMunawir. Surabaya: Pustaka Progressif

Uman, Cholil, et.al. 1995. Kamus Pintar Agama Islam,Bandung: Citra Umbara.

Paden, William A.1994. Religious World Massachussets: Beacon Press

Triyanta, Agus.2002. Pandangan Tarekat Naqsabandiyah temadap Konservasi Alam, penelitian individual Lembaga Penelitian Universitas Islam Indonesia.

Yahya, Harun. 1999. Persihed Nations, translasi ke Inggris, Ahmad, Mustapha, London: Ta-Ha Publisher Ltd.

Al-Qur'an dan Terjemahnya, Departemen Agama Rl. 